\title{
Ensuring Effective and Efficient Humanitarian Logistical Services Delivery: The role of Disaster Relief Organisations in Ghana
}

\author{
Article by Japhet Baidoo \\ Disaster Management, Texila American University \\ Email: japhetbaidoo@yahoo.com
}

\begin{abstract}
Sudden natural disasters, such as hurricanes, earthquakes, floods and tsunamis usually generate destruction on impact, injuring people, rendering many homeless and imposing huge cost to governments by destroying public infrastructure. Considering the adverse effects on properties, human life and the economy at large, it is important to pay particular attention to humanitarian logistics as a vital medium for responding to present disasters and preparing for future ones. This study examined the factors and mechanisms for humanitarian logistical services delivery in Ghana. The case study focused on humanitarian and relief organizations operating in Ghana. Questionnaires and in-depth interviews were used to gather data from officials of ten disaster relief organizations. Findings from the study revealed important factors for effective and efficient disaster relief operations. Despite financial and logistical challenges, humanitarian organizations have put in place mechanisms for dealing with emergencies. Disaster relief organizations operating in Ghana should adopt innovative and responsive mechanisms in humanitarian relief operation so as to achieve agility.
\end{abstract}

Keywords: Humanitarian Logistics, Natural Disaster, Relief Organisations. Innovative and Responsive Mechanisms.

\section{Introduction}

Over the last two decades, humanitarian logistics has received tremendous attention in both field of human endeavour and scholarly research. The evolving trend of humanitarian logistics was triggered by series of disasters that erupted in the world and their attendant problems. For instance, the 2004 Indian Ocean Tsunami disaster generated unprecedented global outcries regarding poor logistics management. This disaster and the criticisms of its management provided a turning point for humanitarian logistics (Kovacs \& Spens, 2011). In 2006, came actual breakthrough for humanitarian logistics management with far improved performance and responsiveness to disaster situations.

In effect, coordination and collaboration of among humanitarian organizations became more challenging in the use of local logistics and human resources in humanitarian relief operations (Overstreet at al., 2011). Unfortunately, disasters upon disasters keep striking and disaster reliefs have also become increasingly demanding making humanitarian logistics globally more challenging, given the complexities and uncertainties involved (Díaz-Delgado and Iniestra, 2014). Ghana is no exception in this regard, as in the past two decades the country has experienced series of disasters that have had devastating social-economic and political consequences. For example, devastating flood disasters that affected Ghana in the last decade occurred in 2003, 2007, 2009, 2010 and 2015. The 2010 and 2015 were the most devastating in recent memory in terms of morbidity, mortality, destructions of physical infrastructures, economic and social adverse effects (Ntanjal, et al, 2017). In terms of epidemics, cholera is regarded as an entrenched disaster posing great concern in Ghana (Osei, 2010). In 2014 cholera occurred in 130 districts out of the 216 districts in Ghana recording 28,975 cases with a death toll of 243 (WHO, 2015). This outbreak protracted and had a spill over to 2015 recording 591 cases with 5 deaths as at May, 2015. The cholera epidemic is found to be fostered and triggered by heavy rains and floods across Ghana (WHO, 2015). These examples of disasters cannot go without the mention of fire disaster which is found to be an annual catastrophic occurrence and its prevalence is very high. Fire disasters in Ghana is said to cost the nation in terms of value of properties destroyed to the tune of US\$16million annually (Addai, et al, 2016). 


\section{Statement of the problem}

All the above examples of disasters in Ghana are indication of the fact the need for effective response to disasters in Ghana cannot be over-emphasized. This call has been echoed by Van Wassenhove (2006:480) that "a successful response to a disaster is not improvised. The better one is prepared the more effective the response" (Van Wassenhove, 2006: 480). However, in most cases response to disasters by humanitarian and relief organizations Ghana is fraught with challenging constraints making rapid response ineffective (Buatsi, 2007). This notwithstanding, studies on disaster management in Ghana have centred on the type of disasters and their effects on the country's growth and development. These studies have focused on earthquakes (Allotey, Arku \& Amponsah, 2010; Oteng-Ababio, 2013), floods (Osei, 2010; Nyarko, 2010; Bempah and Olyhus, 2017; Ntanjal, et al, 2017), fires (Sam-Okyere, 2010; Sarpong, 2013; Addai, et al, 2016) and epidemics (Amposah, 2004; Annan, Addai and Tulashie, 2016; Tulashie and Annan, 2016). Relatively, few studies have paid attention to humanitarian logistics especially the roles of various disaster relief organizations in ensuring timely and effective management of disasters. Hence, it is important to critically examine the roles of disaster relief organisations in responding to disasters in Ghana.

\section{Objectives of the study}

The main aim objective of the study is to examine humanitarian logistical services delivery in Ghana. The specific objectives are:

i. To examine the factors that account for effective humanitarian logistical services delivery.

ii. To assess mechanisms for disaster relief operations in Ghana.

\section{Research questions}

The study is guided by the following research questions:

i. What factors that account for effective humanitarian logistical services delivery?

ii. What are the mechanisms for responding to emergencies during disaster relief operations?

\section{Theoretical framework}

The study is underpinned by the Humanitarian Space framework. This refers to space created by disaster relief organizations to suitably conduct humanitarian work. Based on the situation or condition in the field, creating and maintaining humanitarian space pose as challenge since space is dynamic and changes rapidly. For example, weather condition can result in hindering success to certain areas, whilst similar effect in natural disasters and security could as well encounter same challenge. According to Tomasini \& Van Wassenhove (2009), it is the aim of all humanitarians to live and operate within humanitarian space, which exists in a physical and a virtual sense. They explained that in the physical sense, humanitarian space represents a zone where non-combatants, civilians, and aid workers are protected from attack and violence and can operate and move freely.

When the present government is part of the conflict, it is complex to establish humanitarian space for political conflicts essentially. In the virtual sense, humanitarian space is the interaction between the different members of the humanitarian ecosystem, and how to create a location where their mandates can be carried out. It is easier to define humanitarian space in terms of natural disasters, as different parties and the government often share fundamental goals. Figure 1 illustrates the humanitarian triangle and the underlying principles governing its operation. 


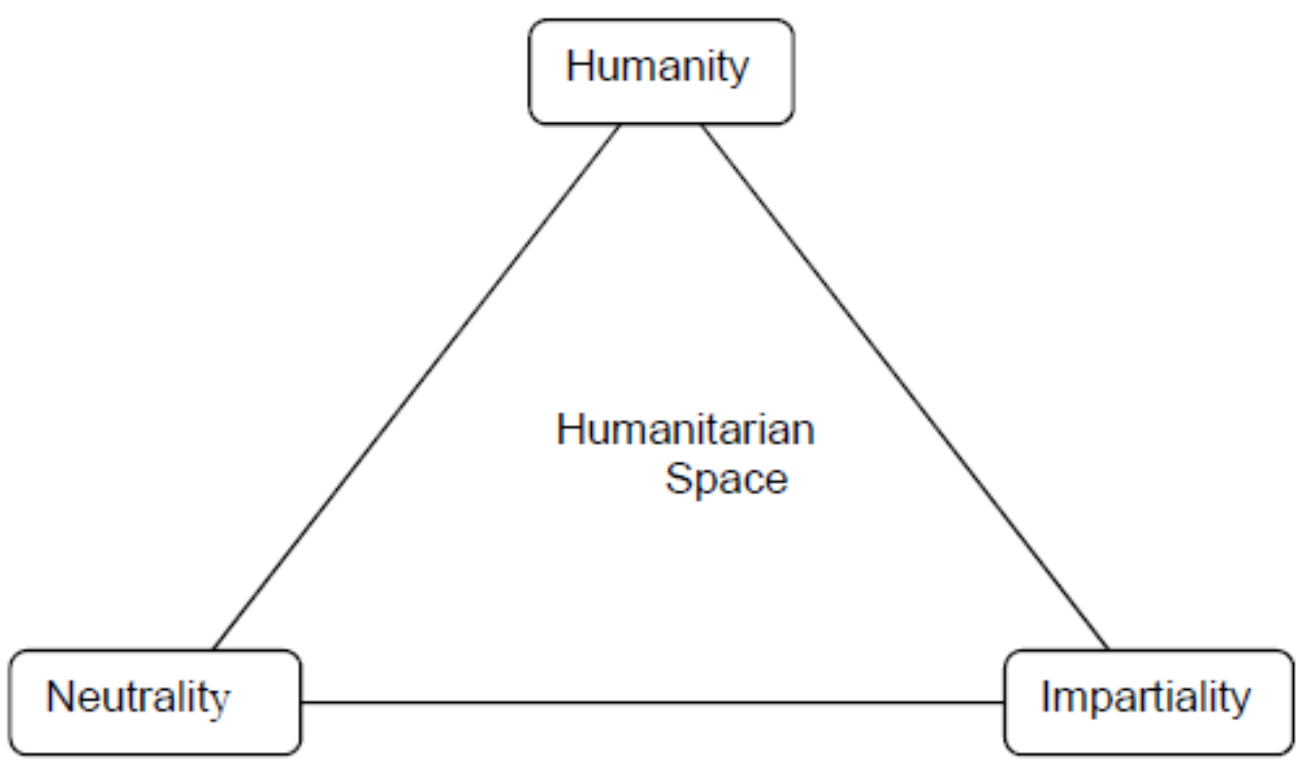

Figure 1. Humanitarian space and principles

Source: Tomasini and van wassenhove (2009).

Since all the three principles are of equal weight the triangle it is said to be an equilateral. As humanitarian agencies and disaster relief organizations attempt to maintain balance, any compromise on a principle may have effect on the size and shape of the triangle, thus, influencing the outcome of the crises and the agencies' ability to operate. The area bounded by the triangle is therefore referred to as the humanitarian space.

In the humanitarian network, the focus is on managing the flow of goods, finance and information, from donors to affected persons in a not-for-profit manner. Hence, when analyzing and structuring humanitarian logistics, three (3) main processes are key-fulfillment management, supply management and demand management (Ernest, 2003). In addition to managing resources, it is important to recognize that different actors are involved As Kova'cs and Spens (2007) opined, in humanitarian logistics, there are many participants involved some of whom are not linked to the benefits of fulfilling demand. Participants such as governments, donors, security services (military, police, etc.,) NGOs, and logistics providers perform significant roles in humanitarian relief operations. The same applies to distributors, suppliers, retailers and manufacturers located in the commercial supply network. In Ghana, National Disaster Management Organization (NADMO), is the lead government agency responsible for disaster management (Oteng-Ababio, 2013a). It is supported mainly by the security services such as Ghana National Fire Service, and Ghana Police Service. The establishment of the National Ambulance Service recently is intended to argument the work of NADMO and assist ion recovery operations (Sarpong, 2013).

\section{Methods}

The study employed quantitative and qualitative research approaches to assess humanitarian logistics and disaster relief organizations in Ghana. The use of mixed methods made it possible for the researcher to explore the research questions from different perspectives which lead to broader understanding of issues relating to topic (Bryman, 2004). Relying on the purposive sampling method, ten humanitarian organizations engaged in disaster and relief operations in Ghana were involved in the study (see Table 1). In each of the organization, a senior official was involved in the study. 
DOI: $10.21522 /$ TIJMG.2015.04.01.Art004

ISSN: $2520-310 \mathrm{X}$

Table 1. Selected organizations for data collection

\begin{tabular}{|l|l|}
\hline No & Name of Organization \\
\hline 1 & United Nations Humanitarian Response Depot (UNHRD \\
\hline 2 & World Vision - Ghana (WVG) \\
\hline 3 & Adventist Development Relief Agency (ADRA) \\
\hline 4 & CARE International \\
\hline 5 & National Disaster Management Organization (NADMO) \\
\hline 6 & Ghana Police Service (GPS) \\
\hline 7 & St. John's Ambulance Service (SAS) \\
\hline 8 & National Ambulance Service (NAS) \\
\hline 9 & Ghana National Fire Service (GNFS) \\
\hline 10 & United Nations High Commission for Refugees (UNHCR) \\
\hline
\end{tabular}

\section{Data collection and analysis}

Data for the study were collected using questionnaire and interviews. This is in one with the mixed methods approach as the underlying philosophy guiding the study. The use of questionnaires ensured that standardized data were collected from identical organizations, in this case, disaster relief organizations engaged in logistics (Yin, 2004). The questionnaires were designed using Likert Scale statements that focused on respondents' roles during emergency relief operations and general disaster management. Interview guide consisting of open-ended questions was designed seek the views on issues related to humanitarian logistics. The SPSS software was used to analyse the data collected from the questionnaires through the Weighted Mean Average formula. The results obtained from the interviews were analysed using thematic analysis framework. In this regard, the study identified the main themes running through the results obtained.

\section{Results and discussion}

\section{Factors for effective and efficient disaster relief operations}

Using Relative Importance Index, (RII), the factors that account for effective humanitarian logistical services delivery were ranked as indicated in Table 2 .

Table 2. Ranked RII Factors for effective and efficient humanitarian logistical services delivery

\begin{tabular}{|l|l|l|}
\hline Types of Disasters & RII & Rank \\
\hline Cost efficiency of aid items procured & 0.40 & $12^{\text {th }}$ \\
\hline Cost efficiency of delivering aid items & 0.48 & $9^{\text {th }}$ \\
\hline Budget allocation for disaster relief operation & 0.38 & $13^{\text {th }}$ \\
\hline Budget allocation for administrative work & 0.34 & $14^{\text {th }}$ \\
\hline Mechanism to eliminate corruption & 0.68 & $3^{\text {rd }}$ \\
\hline Mechanism to check overstaffing & 0.66 & $4^{\text {th }}$ \\
\hline Elimination of duplication of job & 0.70 & $2^{\text {nd }}$ \\
\hline Effective internal control & 0.72 & $1^{\text {st }}$ \\
\hline Avoidance of panic or impulse buying & 0.46 & $10^{\text {th }}$ \\
\hline Effective inventory control & 0.44 & $11^{\text {th }}$ \\
\hline Availability of funds & 0.58 & $6^{\text {th }}$ \\
\hline Availability of supplies & 0.54 & $8^{\text {th }}$ \\
\hline Availability of equipment & 0.56 & $7^{\text {th }}$ \\
\hline Availability of expertise HR & 0.64 & $5^{\text {th }}$ \\
\hline
\end{tabular}

Source: Field data, 2016.

From the Relative Importance Index table above, it was found that the most important factor for effective and efficient disaster relief operation was effective internal control which was ranked first. This finding is consisted with the assertion by Kova'cs and Spens (2007) that effective internal control 
is key to efficient humanitarian service delivery. Next to internal control was elimination of duplication of job $\left(2^{\text {nd }}\right)$. This was followed by mechanism to eliminate corruption $\left(3^{\text {rd }}\right)$, mechanism to check overstaffing $\left(4^{\text {th }}\right)$, availability of HR expertise $\left(5^{\text {th }}\right)$ and availability of funds $\left(6^{\text {th }}\right)$. Other factors identified include availability of infrastructure and equipment $\left(7^{\text {th }}\right)$, availability of supplies $\left(8^{\text {th }}\right)$ and cost efficiency of delivering aid items $\left(9^{\text {th }}\right)$. Thus, the important factors for effective and efficient disaster relief operation were effective internal controls, elimination of duplication of job, mechanism to eliminate corruption and check overstaffing.

\section{Mechanisms for disaster relief operations in ghana}

To effectively respond to disasters and remain efficient in disaster relief operations, humanitarian organizations must develop and implement robust mechanisms for dealing with emergency situations. From the questionnaire results, all the respondents agreed that their respective organisations have effective emergency mechanisms, tools and plans in place to respond to some unpredictable and large scale disasters. In indicating what are these mechanisms, tools, plans or assessments, 8 out of the 10 respondents stated those emergency mechanism, tools, plans or assessments they have in place in response to some unpredictable and large scale disasters (Table 3).

Table 3. Emergency Mechanisms, tools and plans

\begin{tabular}{|c|c|c|}
\hline No. & Organisation & Emergency Mechanisms/tools/plans \\
\hline 1 & $\begin{array}{l}\text { World Vision } \\
\text { Ghana }\end{array}$ & $\begin{array}{l}\text { Emergency Response and Disaster Mitigation Committee, } \\
\text { Community Disaster Preparedness Plans, National Disaster } \\
\text { Preparedness Plan, National Rapid Response Team }\end{array}$ \\
\hline 2 & NADMO & $\begin{array}{l}\text { Disaster Management Plan, Standard Operating Procedure, } \\
\text { Contingency Plans, National Strategic Action Plan, National } \\
\text { Relief and Reconstruction Management Plan }\end{array}$ \\
\hline 3 & $\begin{array}{l}\text { Ghana Red Cross } \\
\text { Society }\end{array}$ & $\begin{array}{l}\text { Trained volunteers in Emergency Response and Warehouse to } \\
\text { stockpile relief items }\end{array}$ \\
\hline 4 & $\begin{array}{l}\text { St. Johns } \\
\text { Ambulance } \\
\text { Service }\end{array}$ & Trained staff and volunteers \\
\hline 5 & $\begin{array}{l}\text { Ghana National } \\
\text { Fire Service }\end{array}$ & Fire Extenders and Fire Fixing Equipment \\
\hline 6 & $\begin{array}{l}\text { Ghana Police } \\
\text { Service }\end{array}$ & Rapid Deployment Station \\
\hline 7 & UNHRD & Inter-agency Emergency Plan \\
\hline 8 & $\begin{array}{l}\text { National } \\
\text { Ambulance } \\
\text { Service }\end{array}$ & Well-equipped ambulance and trained personnel \\
\hline
\end{tabular}

Source: Field data, 2016.

All the respondents stated that their organisations work with other humanitarian organizations. In this respect, $80 \%$ of the respondents strongly agreed that there was effective coordination and collaboration among them and other organizations and $10 \%$ slightly agreed to this view. However, the remaining $10 \%$ strongly disagreed there was effective coordination and collaboration among them and other organizations.

In response to whether the disaster relief organisations have Disaster Management Policy Manual (DMPM), eight of the selected organizations were affirmative. For instance, the Ghana Red Cross Society stated that it has adopted the Standard Operating Procedures (SOP) and applies the SPHERE formula which determine and regulate the appropriation of disaster relief items to victims. The Ghana National Fire Service applied the SOP, similar to Ghana Red Cross Society. It stated that the organisation has Policy Manuals which works in line with the SOP. NADMO stated that it has developed SOP manual to ensure that disaster relief organisations work within specified standards. In addition to the SOP, NADMO and its stakeholders have also developed National Disaster Management 
Plan cataloguing studies and activities that have to be carried out by various responsible agencies for the purpose of ensuring effective disaster management in Ghana. National Ambulance Service stated that it has its own operational policy. In addition, it applies the SOP and Ghana Health Service policies. With respect to ADRA, the organisation indicated that it also applies the SOP and has recently developed a policy manual for its partner-NGOs. According to UNHRD and the Ghana Police Service, they have their own policy manuals but also operate within the confines of the SOP. World Vision Ghana has disaster preparedness policy and follows international guidelines when responding to emergencies.

\section{Conclusion}

Logistics is a central part to any disaster relief operations. Logistics management determine the efficiency and effectiveness of humanitarian relief supply chain and this leads to relief aids being delivered to the right beneficiaries at the right time, in the right place and, in the right quantity. There are a number of issues in humanitarian logistics that need to be addressed in order to achieve effective and efficient humanitarian logistical services delivery. Potential challenges such as funding, transportation problems, poor communication and cumbersome logistical and customs clearance procedures that tend to negatively affect efficacy of humanitarian organisations in performing their roles must be addressed.

\section{Recommendations}

1. Humanitarian relief organisations should adopt more innovative ways of achieving internal control, reducing cost, eliminating corruption and improving efficiency. Hence, the ICT and international financial administration producers will ensure that they are agile and dynamic.

2. Communication is crucial towards ensuring effective logistics service delivery. Humanitarian organizations should improve collaboration by improving the existing platforms for communication and sharing information regarding disaster and emergency relief issues rapidly.

3. Investments in infrastructure in the form of warehouses, equipment and other supplies should be scaled up. Government in collaboration with relief organizations should provide warehouses stocked with supplies in the three ecological zones namely, coastal, forest and savanna. This will help to improve response time to disasters and make organizations more effective in logistical service delivery.

4. Humanitarian organizations should also have local presence for capacity building in terms of education and the pre-positioning of relief items. Capacity building is particularly important in order to overcome the problem of aid dependence and limited supplies.

\section{References}

[1]. Addai, E. K., Tulashie, S.K., Annan, J.S. and Yeboah, I. (2017). Trend of Fire Outbreaks in Ghana and Ways to Prevent These Incidents, Safety and Health at Work 7 (2016) 284-292.

[2]. Allotey, N. K., Arku, G. and Amponsah, P. E. (2010) Earthquake-disaster preparedness: The Case of Accra, International Journal of Disaster Resilience in the Built Environment, 1, 2. 140-156.

[3]. Amponsah, P.K. (2004). Seismic activity in Ghana: Past, present and future. Annals of Geophysics, 47(2/3), 539-543.

[4]. Annan J-S, Addai EK, Tulashie SK. (2015). A call for action to improve occupational health and safety in Ghana and a critical look at the existing legal requirement and legislation. Safety Health Work 2015; 6:146-50. [5]. Bempah, S. A. and Øyhus. A.O. (2017): The role of social perception in disaster risk reduction: Beliefs, perception, and attitudes regarding flood disasters in communities along the Volta River, Ghana, International Journal of Disaster Risk Reduction 23 (2017) 104-108.

[6]. Bryman, A. (2004), Social Research Methods, 3rd ed, Oxford University Press, Oxford. issp:

[7]. Buatsi, S.N. (2007), Humanitarian logistics: context and challenges in Ghana and Africa, International Conference on humanitarian logistics in Ghana.

[8]. Díaz-Delgado, C and Iniestra, J. G. (2014) Flood Risk Assessment in Humanitarian Logistics Process Design. Journal of Applied Research and Technology, 12, 976-984 
[9]. Ernst, R. (2003), The academic side of commercial logistics and the importance of this special issue. Forced Migration Review, 18, p. 5.

[10]. Kopczak, L. R. and Johnson, M. E. (2004), "Can Heroes be Efficient? Information Technology at the International Federation of the Red Cross", the Tuck School of Business at Dartmouth Glassmeyer/McNamee Center for Digital Strategies, Vrs Oct 2004, Kovacs, G. and Spens, K., M. (2007) Humanitarian logistics in disaster relief operations, International Journal of Physical Distribution \& Logistics Management, 7, 2, 99-114. [11]. Ntajal, J., Lamptey, B, L., Mahamadou, I. B. and Nyarko, B.K. (2017). Flood disaster risk mapping in the Lower Mono River Basin in Togo, West Africa International Journal of Disaster Risk Reduction 23 (2017) 93103.

[12]. Nyarko, B.K. (2010). Flood Risk Zoning of Ghana: Accra Experience, International Archives of Photogrammetry and Remote Sensing. Vol. XXXIII, Part B7. Amsterdam, the Netherlands.

[13]. Osei, F. B. (2010), Spatial Statistics of Epidemic Data: The Case of Cholera Epidemiology in Ghana, PhD Thesis, University of Twente, Enschede, Netherlands.

[14]. Oteng-Ababio, M. (2013). Prevention is better than cure: Assessing Ghana's preparedness (capacity) for disaster management. Jamba: Journal of Disaster Risk Studies, 5 (2), 1-11.

[15]. Overstreet, R.E., Hall, D, Hanna, J. B., Rainer, J. and R. Kelly, R (2011). Research in humanitarian logistics. Journal of Humanitarian Logistics and Supply Chain Management, 1 (2011), pp. 114-131

[16]. Sam-Okyere E. (2010). Infernos in our offices; demystifying the facts. The Chronicle. 2010 Feb 25; p. 3. [17]. Sarpong A.O. (2013). Fire risk vulnerability in informal settlements the case of Ashaiman. MS thesis. Accra (Ghana): University of Ghana; 2013. issp:

[18]. Tomasini, R. and Van Wassenhove, L. N. (2009). From preparedness, to partnerships:

[19]. Case study research on humanitarian logistics, International Transactions in Operational Research, 16(5), 549-559.

[20]. Tulashie SK, Addai EK, Annan J-S. (2016). Exposure assessment, a preventive process in managing workplace safety and health, challenges in Ghana. Safety Science, 2016; 84:210-215. istep van Wassenhove, L.N. (2006), Humanitarian aid logistics: supply chain management in high gear, Journal of the Operational Research Society, 57,5. 475-89.

[21]. WHO (2015) Situation Report on Cholera Outbreak in Ghana as of 24 May 2015 (Week 21), Country Office Accra, Ghana.

[22]. Yin, R. K. (2004). Case Study Research: Design and Methods, $3^{\text {rd }}$ Ed. Sage, Thousand Oaks, CA. 